\title{
Retraction Note: Urban land ecological evaluation and English distance teaching evaluation based on wireless sensors
}

Wei $\mathbf{L i}^{1}$

Published online: 3 November 2021

(c) Saudi Society for Geosciences 2021

Retraction Note: Arabian Journal of Geosciences (2021) 14: 1810 https://doi.org/10.1007/s12517-021-08162-4

The Editor-in-Chief and the Publisher have retracted this article because the content of this article is nonsensical. The peer review process was not carried out in accordance with the Publisher's peer review policy. The author does not agree to this retraction.

The original article can be found online at https://doi.org/10.1007/ s12517-021-08162-4.

Wei Li

leslielee32@163.com

1 School of Foreign Languages, Zhengzhou Tourism College, Zhengzhou 450000, Henan, China 